\title{
PENGARUH VISUAL MERCHANDISING DAN STORE ATMOSPHERE TERHADAP IMPULSE BUYING DENGAN POSITIVE EMOTION SEBAGAI VARIABEL MEDIASI PADA KONSUMEN MINISO MALL KARTINI BANDAR LAMPUNG
}

\author{
Ayu Diah Ramaiska ${ }^{(1)^{*}}$, Ayu Putri Lestari ${ }^{(2)}$, Rayhan Muh. Durrasuwawi ${ }^{(3)}$, \\ Vicky F Sanjaya ${ }^{(4)}$
}

Fakultas Ekonomi dan Bisnis Islam Universitas Islam Negeri Raden Intan Lampung ayudiahramaiska@gmail.com, Ayuputrilestari2002@gmail.com,rayhanmds56@gmail.com, vicky@radenintan.ac,id

\begin{abstract}
Abstrak. Perkermbangan industri ritel di Indonesia terus meningkat diikuti oleh permintaan masyarakat Indonesia akan fashion. Penelitian ini bertujuan untuk mengetahui pengaruh visual merchandising dan store atmosphere terhadap impulse buying melalui positive emotion sebagai variabel mediasi. Sampel yang digunakan dalam penelitian ini adalah konsumen Miniso Mall Kartini dengan jumlah 73 responden. Uji statistik dilakukan dengan menggunakan Structurel Equation Modelling berbasis PLS. Uji validasi menggunakan menggunakan nilai factor loading, sedangkan uji reliabilitas menggunakan nilai cronbach's alpha, composite reliability dan average variance extracted (AVE). Setelah seluruh hasil item indikator yang digunakan dalam penelitian ini valid dan reliabel, selanjutnya akan dilakukan uji hipotesis. Dari lima hipotesis yang diajukan seluruhnya 4 hipotesis terdukung sedangkan 1 hipotesis tidak terdukung. Kesimpulan dari penelitian ini adalah store atmosphere tidak dapat berpengaruh pada impulse buying tetapi dengan adanya positive emotion akan mempengaruhi atau memediasi hubungan tidak langsung dua variabel tersebut.
\end{abstract}

Kata kunci: Visual Merchandising, Store Atmosphere, Positive Emotion dan Impulse Buying.

\section{PENDAHULUAN}

Pada era modern seperti sekarang, persaingan bisnis berkembang dengan pesat. Pertumbuhan bisnis ritel di Indonesia adalah salah satu bisnis yang sangat terasa perkembangannya. Fenomena bisnis ritel biasanya sering kali dilihat sebagai gambaran perekonomian negara. Namun pada tahun 2017 lalu merupakan kondisi yang kurang menyenangkan bagi industri ritel di Indonesia. Pasalnya terjadi penurunan yang signifikan yang dapat dilihat dari banyaknya peritel dibeberapa kota di Indonesia yang gulung tikar dan meutup gerainya dibeberapa cabang. Pernyataan ini juga diperkuat oleh bukti dari hasil riset Global Retail Development Index ${ }^{\mathrm{TM}}$ oleh Kearney (2017) yang menunjukan pada tahun 2017 kondisi ritel di
Indonesia sedang menurun. Jika dilihat dari kedua tabel dibawah, pada tahun 2017 Indonesia berada diposisi kedelapan yang artinya turun tiga peringkat dari tahun 2016.

Dengan dibukanya gerai-gerai merek internasional di Indonesia diprediksi permasalahan diatas tidak akan berlanjut. Jumlah brand bertaraf internasional semakin bertambah karena Indonesia dinilai sebagai pasar yang potensial (Sudarsono, 2017). Hal ini didukung oleh faktor life style dan perilaku pembelian konsumen yang sudah mulai berubah. Hal ini mengubah pola belanja konsumen yang pada awalnya melakukan pembelian terencana menjadi tidak terencana atau impulse buying .

Impulse buying merupakan keputusan pembelian yang dilakukan di dalam toko dengan tidak adanya pengakuan 
eksplisit akan kebutuhan atas pembelian tersebut sebelum masuk ke toko (Kollat \& Willett, 1969). Kehadiran ritel asing yang terus meningkat memaksa setiap toko berusaha membuat pelanggan memasuki toko dan melakukan pembelian melalui pemanfaatan visual merchandising.

Visual merchandising merupakan teknik dalam mempresentasikan tampilan barang dagangan yang menaik eye catching dan ditujukan pada pelanggan potensial (Jain et al., 2012). Tujuan utama pengecer adalah agar toko mereka dapat menarik konsumen dan membantu konsumen menemukan barang yang diinginkan serta mendorong untuk melakukan pembelian yang tidak direncanakan dan memberikan pengalaman berbelanja yang menyenangkan.

Selain visual merchandising yang dapat memperngaruhi impulse buying ternyata masih banyak variabel lainnya seperti store atmosphere. Store Atmosphere adalah keadaan toko yang didesain semanarik mungkin untuk memperngaruhi konsumen dalam melakukan pembelian. Store atmosphere adalah langkah untuk memanipulasi desain bangunan, ruang interior, tata ruang lorong-lorong, bau, warna, dan suara yang dialami para pelanggan untuk mencapai pengaruh tertentu (Ratnasari et al., 2015).

Positive emotion adalah salah satu faktor penting yang ikut berkontribusi dalam mempengaruhi impulse buying. Positive emotion dapat diartikan sebagai suasana hati yang mempengaruhi dan menentukan intensitas pengambilan keputusan konsumen (Rachmawati, 2009). Penelitian ini juga menutup celah dari peneliti sebelumnya yang menyatakan bahwa positive emotion tidak berpengaruh terhadap impulse buying. Selain itu peneliti sebeliumnya menyarankan untuk mengganti subjek penelitian dengan perusahaan ritel lainnya untuk melihat apakah variabel-variabel yang diteliti memberikan hasil yang serupa apabila diterapkan pada perusahaan lainnya.
Miniso merupakan salah satu ritel yang mendeskripsikan dirinya sebagai fast fashion brand. Sejak didirikan tahun 2013 di Tiongkok, Miniso langsung secara aktif memaksimalkan potensi pasar internasional. Hanya dalam kurun waktu empat tahun, perusahaan ini secara global meraup pendapatan hingga U\$\$ 2 miliar. Angka ini melonjak $100 \%$ dibandingkan tahun sebelumnya. Tepat pada tahun 2017 Miniso mulai memasuki pasar Indonesia di tengah lemahnya industri ritel pada tahun itu. Dalam kurun waktu kurang dari satu tahun Miniso telah membuka sebanyak 88 gerai dibeberapa daerah. Hingga saat ini Miniso telah memiliki hampir 200 gerai yang tersebar di Indonesia (Sumber: Minsoindo).

Miniso adalah toko ritel yang menampilkan visual yang berbeda dari toko ritel lain. Penggunaan kaca besar dengan rak memanjang ke atas, pencahayaan yang cukup serta penggunaan warna yang dominan pastel sehingga terkesan lebih elegan dan menarik minat konsumen. Konsumen miniso juga terbilang banyak dan beragam serta penulis pun merasakan proses pembelian impulsif pada saat memasuki gerai Miniso. Hal ini yang melatar belakangi peneliti untuk melakukan penelitian dengan judul "Pengaruh Visual Mercahandising dan Store Atmosphere terhadap Impulse Buying melalui Positive Emotion sebagai Variabel Mediasi pada Konsumen Miniso Mall Kartini”.

\section{TEORI DAN HIPOTESIS}

\section{Visual Merchandising terhadap Impulse Buying}

Visual merchandising ialah teknik dalam mempresentasikan tampilan barang dagangan dengan sangat menarik (eye catching) dan dirtujukan pada pelanggan potensial (Jain et al., 2012). Berdasarkan hasil penelitian yang dilakukan oleh (Pancaningrum, 2017) menunjukan bahwa 
visual merchandising memiliki pengaruh positif daan signifikan terhadap impulse buying konsumen. Hal ini juga sejalan dengan penelitian yang dilakukan oleh (Hartaroe et al., 2016) menunjukan bahwa visual merchandising berpengaruh langsung terhadap impulse buying. Dalam penelitian yang dilakukan oleh (Sudarsono, 2017) menunjukan bahwa terdapat pengaruh antara visual merchandising terhadap impulse buying namun tidak signifikan. Berbeda dengan (Fazri et al., 2020) dalam penelitiannya menunjukan visual merchandising berpengaruh secara negatif namun tidak signifikan terhadap impulse buying. Sehingga berdasarkan hal di atas penulis membuat hipotesis:

\section{H1 : Visual Merchandising berpengaruh positif terhadap Impulse Buying}

\section{Store Atmosphere terhadap Impulse Buying}

Semakin menarik suasana toko yang ditawarkan oleh perusahaan ritel makan akan meningkatkan pembelian secara impulsif para konsumen (Ariani Darmayasa \& Sukaatmadja, 2017). Berdasarkan hasil penelitian dari (Pancaningrum, 2017), menunjukan bahwa store atmosphere memiliki pengaruh positif dan signifikan terhadap pembelian impulsif konsumen. (Kwan, 2016) menunjukan bahwa store atmosphere memiliki pengaruh yang signifikan terhadap impulse buying. Hal ini juga didukung oleh penelitian yang dilakukan (Hanafi \& Hutomo, 2019) yang menghasilkan bahwa store atmosphere secara persial berpengaruh terhadap impulse buying. Berbeda dengan peneliti di atas, penelitian yang dilakukan oleh (I Putu Widya Artana, 2019) menunjukn bahwa store atmosphere tidak memiliki pengaruh yang signifikan terhadap impulse buying. Sehingga berdasarkan hal di atas penulis membuat hipotesis:

\section{H2 : Store Atmosphere berpengaruh positif terhadap Impulse Buying}

\section{Visual Merchandising terhadap Positive Emotion}

Sebagian besar keputusan konsumen dibuat saat berada di dalam gerai. Visual merchandising berpengaruh terhadap positive emotion, yang artinya kualitas indera penglihatan konsumen dipuaskan oleh desain tampilan serta merasa nyaman, maka pada saat itulah timbul emosi positif pada konsumen. Oleh karena itu, semakin baik perusahaan mendesain visual merchandising secara indah, maka emosi pengunjung akan semakin positif (Sudarsono, 2017). Hal ini sejalan dengan penelitian yang dilakukan oleh Putri et al, (2019) menunjukan bahwa visual merchandising berpengaruh langsung terhadap positive emition. Sama dengan peneliti di atas Fazri et al, (2020) dalam penelitiannya menunjukan bahwa visual merchandising berpengaruh secara positive dan signifikan terhadap positive emotion. Sehingga berdasarkan hal di atas penulis membuat hipotesis:

H3: Visual merchandising berpengaruh positif terhadap positive emotion

\section{Store Atmosphere terhadap Positive Emotion}

Store atmosphere merupakan salah satu elemen bauran pemasaran ritel yang terkait dalam hal penciptaan suasana belanja. Store atmosphere adalah desain lingkungan melalui komunikasi visual pencahayaan, warna, musik, dan wangiwangian untuk merancang respon emosional dan persepsi pelanggan dan untuk mempengaruhi pelanggan dalam membeli barang (Nofiawaty, 2014).

Berdasarkan penelitian dari (Kwan, 2016) menunjukan bahwa store atmosphere 
berpengaruh signifikan tehadap positive emotion. Penelitian yang dilakuakn oleh (Devi \& Nurcaya, 2020) pun menunjukan bahwa store atmosphere berpengaruh positive dan signifikan terhadap positive emotion. Artinya semakin baik store atmosphere, maka positive emotion yang akan dirasakan oleh konsumen akan meningkat juga. Hal ini juga dibuktikan oleh (Diany et al., 2019) dalam hasil penelitiannya yang menunjukan bahwa store atmosphere berpengaruh signifikan terhadap positive emotion.

Berbeda dengan peneliti yang lain, penelitian yang dilakukan oleh Fazri et al, (2020) menunjukan bahwa store atmosphere berpengaruh secara negatif dan tidak signifikan terhadap emosi positif. Sehingga berdasarkan hal di atas penulis membuat hipotesis:

\section{H4: Store Atmosphere berpengaruh positif terhadap positive emotion}

\section{Positive Emotion terhadap Impulse Buying}

Ketika seseorang dengan emosi positif akan membuat orang tersebut memiliki gairah dalm berbelanja. Berbagai macam produk yang dinilai menarik akan dibeli meskipun tidak ada perencanaan sebelumnya untk memuaskan rasa senang yang di alaminya. Jika masyarakat dalam keadaan senang maka cenderung menciptakan impulse buying. berdasarkan hasil penelitian (Sucidha, 2019) menyatakan bahwa positive emotion berpengaruh positif dan signifikan. Artinya semakin tinggi positive emotion maka semakin tinggi pula impulse buying. Hal ini sejalan dengan penelitian yang dilakuakan oleh (Sudarsono, 2017) menunjukan bahwa terdapat pengaruh positif antara positive emotion terhadap impulse buying. Hal ini juga didukung oleh Lubaba (2019) dalam penelitiannya menunjukan bahwa dengan adanya positive emotion maka akan meningkatkan impulse buying. Tetapi hal di atas berbeda dengan penelitian yang dilakukan oleh (Sopiyan dan Kusumadewi, 2020) yang menunjukan bahwa positive emotion tidak berpengaruh terhadap impulse buying. Artinya tinggi rendahnya perilaku impulse buying pada konsumen tidak ditentukan oleh perasaan positifnya. Sehingga berdasarkan hal di atas penulis membuat hipotesis:

\section{H5 : Positive Emotion berpengaruh positif terhadap Impulse Buying.}

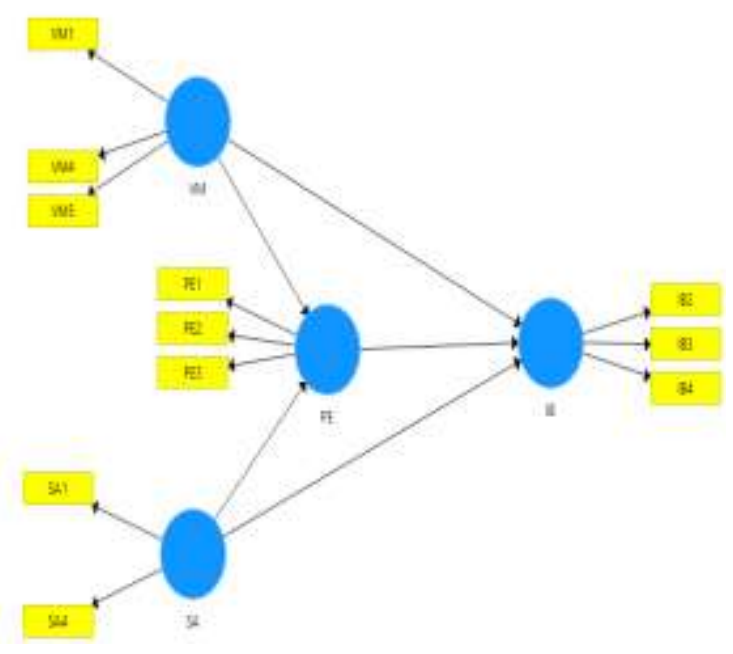

Dengan demikian berdasarkan uraian tersebut peneliti tertarik untuk meneliti tentang Pengaruh visual matketing dan store atmosfer Terhadap Impulse Buying Dengan Positive Emotion Sebagai Variabel Mediasi Pada Konsumen Miniso Mall Kartini Bandar Lampung 


\section{METODE PENELITIAN}

Penelitian ini merupakan penelitian survey dengan bantuan instrumen kuesioner yang dilakukan secara cross sectional atau pada satu waktu tertentu. Level penelitian ini adalah individu dengan karakteristik berbagai generasi mulai dari generasi X, Y, dan Z. Responden merupakan orang yang pernah berkunjung dan berbelanja di Miniso Mall Kartini. Uji validitas instrumen penelitian menggunakan face validity dengan melakukan diskusi dengan expert. Uji validitas selanjutnya adalah convergent validity dengan melihat masing-masing indikator factor loading pada item kuesioner. Convergent validity akan diukur dengan melihat nilai minimum factor loading masing -masing item indikator $\geq 0.6$ (Hair et al., 2010)

Pengujian reliabilitas dengan melihat konsistensi nilai cronbach's alpha minimal 0.6. Pengujian reliabilitas selanjutnya dengan melihat reliabilitas komposit, dan Average Variance Extracted (AVE) $>1$. Jumlah sampel yang didapat sebanyak 110 , tetapi hanya ada 73 responden yang dapat diujikan. Pengujian hipotesis dilakukan dengan menggunakan Structurel Equation Modelling berbasis PLS.

\section{HASIL DAN PEMBAHASAN}

Berdasarkan hasil uji yang dilakukan memiliki beberapa hasil diantaranya. Terdapat beberapa item kuesioner yang gugur karena tidak memenuhi batas standar factor loading. Pada konstruk Visual Merchandising (VM) dari 5 item tersisa 3 item. Konstruk Store Atmosphere (SA) tersisa 2 item dari 4 item. Selanjutnya kontruk Impulse buying dari 5 item tersisa 3 item dan untuk kontruk Positive Emotion dari 4 item tersisa 1 item.

Kemudian dilakukan pengujian ulang terhadap validitas konstruk sehingga semua item indikator berada di atas standar nilai factor loading di atas 0.6 sehingga berdasarkan (Hair et al., 2010) dianggap semua item tersebut valid. Pengujian terhadap reliabilitas memiliki nilai cronbach's alpha, reliabilitas komposit dan Average Variance Extracted (AVE) > 0.6. sehingga instrumen tesebut dianggap reliable dan memenuhi syarat untuk dilakukan pengujian hipotesis.

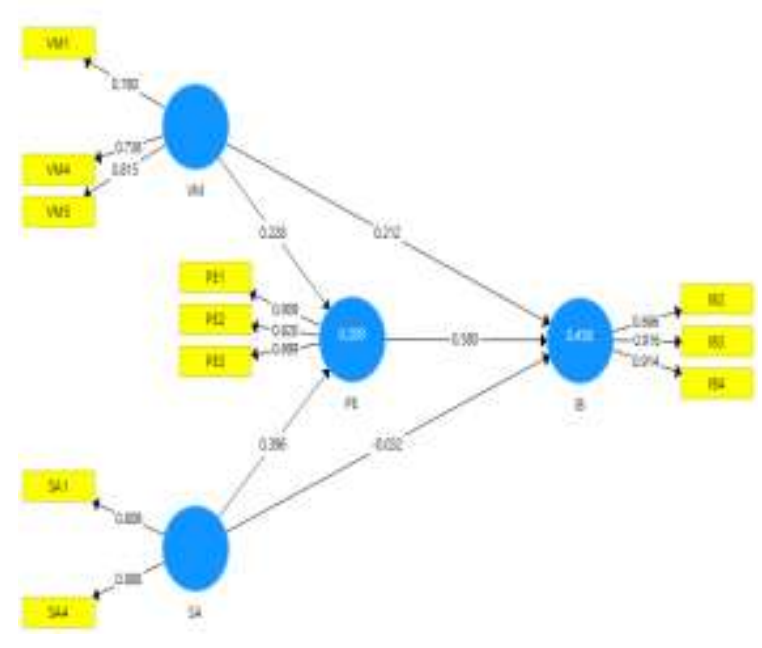

Keterangan:

$\begin{array}{ll}\text { VM } & \text { : Visual Merchandising } \\ \text { SA } & \text { : Store Atmosphere } \\ \text { PE } & \text { : Positive Emotion } \\ \text { IB } & \text { : Impulse Buying }\end{array}$

Tabel 1

Hasil Uji Validitas dan Reliabilitas

\begin{tabular}{ccccc}
\hline \multicolumn{5}{c}{ Uji Validitas } \\
ITEM & VM & SA & PE & IB \\
\hline VM 1 & 0.780 & & & \\
VM 4 & 0.736 & & & \\
VM 5 & 0.815 & & & \\
SA 1 & & 0.809 & & \\
SA 4 & & 0.888 & & \\
PE 1 & & & 0.909 & \\
PE 2 & & & 0.820 & \\
PE 3 & & & 0.699 & \\
IB 2 & & & & 0.696 \\
IB 3 & & & & 0.916 \\
IB 4 & & & & 0.914 \\
\hline
\end{tabular}


Tabel 2

\begin{tabular}{cccc}
\hline Item & Cronbach's Alpha & Uji Reliabilitas \\
\hline IB & 0.800 & 0.884 & $\begin{array}{c}\text { Average Variance } \\
\text { Extracted (AVE) }\end{array}$ \\
PE & 0.745 & 0.853 & 0.720 \\
SA & 0.618 & 0.838 & 0.663 \\
VM & 0.674 & 0.821 & 0.721
\end{tabular}

\section{Hasil Uji Hipotesis}

Hipotesis 1 : Visual merchandising berpengaruh positif terhadap impulse buying. berdasarkan hasil pengujian yang telah dilakukan didapatkan bahwa visual merchandising berpengaruh positif namun tidak signifikan terhadap impulse buying dengan nilai P-Value (0.066>0.05) sehingga dapat disimpulkan bahwa hipotesis 1 terdukung. Hal ini sejalan dengan penelitian yang dilakukan oleh (Sudarsono, 2017) yang menyatakan bahwa terdapat pengaruh antara visual merchandising terhadap impulse buying namun tidak signifikan. Hal ini diakibatkan karena penguasa pembelian di bisnis ritel, termasuk Miniso adalah anak muda. Bagi konsumen remaja visual merchandising bukanlah faktor utama yang digunakan sebagai bahan pertimbangan dalam berbelanja.

Hipotesis 2 : Store atmosphere berpengaruh negatif namun tidak signifikan terhadap impulse buying. berdasarkan hasil uji yang telah dilakukan, didapat nilai PValue $\quad(0.774>0.05) \quad$ sehingga dapat disimpulkan bahwa hipotesis 2 tidak terdukung. Hal ini sejalan dengan penelitian yang dilakukan oleh (I Putu Widya Artana, 2019) yang menyatakan bahwa store atmosphere tidak mempunyai pengaruh yang signifikan terhadap impulse buying.
Hipotesis 3 : Visual merchandising berpengaruh positif dan signifikan terhadap positive emotion . berdasarkan hasil uji yang telah dilakukan, didapat nilai P-Value $(0.033<0.05)$ sehingga dapat disimpulkan bahwa hipotesis 3 didukung. Visual merchandising ini memberikan dampak positif dikarenakan semakin indah visual merchandising akan semakin meningkat pula perasaan senang konsumen yang melihatnya. Hal tersebut sejalan dengan penelitian (Sudarsono, 2017) yang menyatakan bahwa semakin baik perusahaan mendesain visual merchandising secara indah, maka emosi pengunjung akan semakin positif.

Hipotesis 4 : Store atmosphere berpengaruh positif dan signifikan terhadap positive emotion. Bedasarkan hasil uji yang telah dilakukan, didapat nilai P-Value $(0.000<0.05)$ sehingga dapat disimpulkan bahwa hipotesis 4 didukung. Artinya semakin baik store atmosphere maka positive emotion yang akan dirasakan konsumen semakin meningkat juga. Hal ini sejalan dengan penelitian yang dilakuakan oleh (Devi \& Nurcaya, 2020) menunjukan bahwa store atmosphere berpengaruh positif dan signifikan terhadap positive eotion.

Hipotesis 5 : Positive emotion berpengaruh positif dan signifikan terhadap impulse buying. Berdasarkan hasil uji yang telah dilakukan, didapat nilai P-Value 
$(0.000<0.05)$ sehingga dapat disimpulkan bahwa Hipotesis 5 didukung. Hal ini sejalan dengan hasil penelitian yang dilakukan oleh (Sudarsono, 2017) yang menyatakan bahwa terdapat pengaruh positif antara positive emotion terhadap impulse buying.

\begin{tabular}{cc}
\hline Hipotesis & Hasil \\
\hline Hipotesis 1 & Terdukung \\
Hipotesis 2 & Tidak Terdukung \\
Hipotesis 3 & Terdukung \\
Hipotesis 4 & Terdukung \\
Hipotesis 5 & Terdukung \\
\hline
\end{tabular}

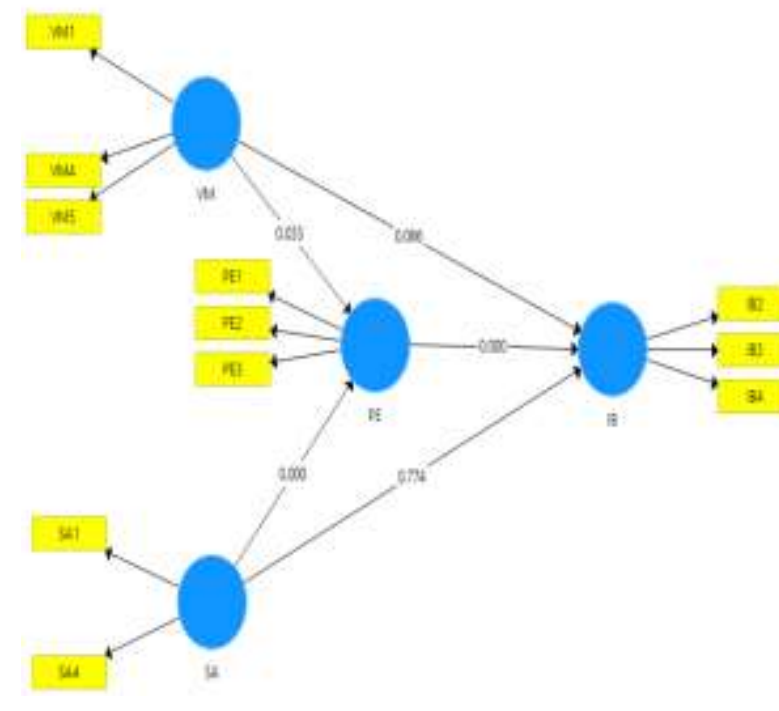

Uji selanjutnya yaitu uji mediasi, pada penelitian ini disimpulkan bahwa mediasi terbukti secara penuh (fully mediating) dan tidak memediasi (no mediation). Hal tersebut dapat dibuktikan dari hasil uji mediasi pertama antara variabel store atmosphere (SA) berpengaruh positif dan signifikan terhadap positive emotion (PE) memiliki nilai 0.000 namun variabel sotore atmosphere (SA) negatif dan tidak signifikan terhadap variabel impulse buying (IB) memiliki nilai 0.774 karena nilai $\mathrm{P}$ berada di atas 0.05 , sehingga uji mediasi pertama dianggap tebukti secara penuh (fully mediating). Pada uji mediasi kedua antara variabel visual merchandising (VM) berpengaruh positif dan signifikan terhadap positive emotion (PE) memiliki nilai 0.033 namun variabel visual merchandising tidak signifikan terhadap variabel impulse buying (IB) memiliki nilai 0.066, sehingga uji mediasi kedua dianggap tidak terbukti (no mediation). Artinya positive emotion tidak memediasi antara visual merchandising terhadap impulse buying.

\section{KESIMPULAN DAN SARAN}

\section{Kesimpulan}

Dari hasil pengujian yang telah dibahas diatas dapat disimpulkan bahwa visual merchandising berpengaruh positif namun tidak signifikan terhadap impulse buying dengan nilai P-Value (0.066>0.05) hal ini karena penguasa pembelian di bisnis ritel, termasuk Miniso adalah anak muda. Bagi konsumen remaja visual merchandising bukanlah faktor utama yang digunakan sebagai bahan pertimbangan dalam berbelaja. Store atmosphere berpengaruh negatif namun tidak signifikan terhadap impulse buying dengan nilai $\mathrm{P}$-Value $(0.774>0.05)$ hasil hipotesis ini tidak terdukung Karena menurut I Putu Widya artana 2019 menyatakan bahwa store atmosphere tidak mempunyai pengaruh yang signifikan terhadap impulse buying. Visual merchandising berpengaruh positif terhadap positive emot ion.

Berdasarkan hasil uji yang telah dilakukan, didapat nilai P-Value $(0.033<0.05)$ yang artinya kualitas indera penglihatan konsumen dipuaskan oleh desain tampilan serta rasa nyaman, yang membuat timbulnya emosi positif terhadap konsumen. Oleh karena itu, semakin baik perusahaan mendesain visual merchandising secara indah, maka emosi pengunjung akan semakin positif. Store Atmosphere berpengaruh positif terhadap positive emotion, bedasarkan hasil uji yang telah dilakukan, didapat nilai P-Value $(0.000<0.05)$ Artinya semakin baik store atmosphere maka positive emotion yang 
akan dirasakan konsumen semakin meningkat juga. Dalam suatu perusahaan disarankan untuk melengkapi ruangan dengan visual pencahayaan, warna, musik, dan wangi-wangian untuk merancang respon emosional dan persepsi pelanggan dan untuk mempengaruhi pelanggan dalam membeli suatu barang. Positive Emotion berpengaruh positif dan signifikan terhadap Impulse Buying, berdasarkan hasil uji yang telah dilakukan, didapat nilai P-Value $(0.000<0.05)$ hasil penelitian ini juga didukung dari hasil penelitian (Sudarsono, 2017)

\section{Saran}

\section{Bagi perusahaan}

Seperti yang sudah di jelaskan bahwa, Visual merchandising merupakan teknik dalam mempresentasikan tampilan barang dagangan yang menaik sehingga dapat memperngaruhi impulse buying dan juga masih banyak variabel lainnya. Adapun store atmosphere adalah keadaan toko yang didesain semanarik mungkin untuk memperngaruhi konsumen dalam melakukan pembelian. Store atmosphere juga langkah untuk memanipulasi desain bangunan, ruang interior, tata ruang loronglorong, bau, warna, dan suara yang dialami para pelanggan untuk mencapai pengaruh tertentu atau bisa juga di sebut dengan positif emotion. Dalam hal ini perusahaan diharapkan bisa memaksimalkan store atmospherenya, sehingga bisa meningkatkan implus buying dan memberikan positife emotion kepada pelanggan yang datang mengunjungi tempat tersebut.

Bagi peneliti selanjutnya

Adapun beberapa saran yang perlu diperhatikan bagi peneliti selanjutnya yang tertarik meneliti tentang Pengaruh Visual Merchandising Dan Store Atmosphere Terhadap Impulse Buying Dengan Positive Emotion Sebagai Variabel Mediasi Pada Konsumen Miniso Mall Kartini Bandar Lampung adalah :

1. Peneliti selanjutnya diharapkan untuk mengkaji lebih banyak sumber maupun referensi yang terkait dengan Visual Merchandising Dan Store Atmosphere Terhadap Impulse Buying Dengan Positive Emotion agar hasil penelitiannya dapat lebih baik dan lebih lengkap lagi.

2. Peneliti selanjutnya diharapkan lebih mempersiapkan diri dalam proses pengambilan dan pengumpulan dan segala sesuatunya sehingga penelitian dapat dilaksanakan dengan lebih baik. Peneliti selanjutnya diharapkan ditunjang pula dengan wawancara dengan sumber yang kompeten dalam kajian Visual Merchandising Dan Store Atmosphere Terhadap Impulse Buying Dengan Positive Emotion.

\section{DAFTAR PUSTAKA}

Ariani Darmayasa, I. A., \& Sukaatmadja, I. (2017). Analisis Pengaruh Store Atmosphere Dan Sales Promotion Terhadap Emotional Shopping Dan Impulse Buying Behavior. None, 6(11), 254006

Devi, D. A. C., \& Nurcaya, I. N. (2020). Peran Positive Emotion Memediasi Store Atmosphere Terhadap Impulse Buying Di Beachwalk Kuta Bali. EJurnal Manajemen Universitas Udayana, $\quad 9(3), \quad 884$. https://doi.org/10.24843/ejmunud.2020 
.v09.i03.p04

Diany, A. A., Sangen, M., \& Faisal, I. (2019). Pengaruh Sales Promotion Dan Store Atmosphere Terhadap Positive Emotion Dan Perilaku Impulse Buying Di Departement Store Matahari Duta Mall, Banjarmasin. JWM (Jurnal Wawasan Manajemen), 7(1), 65. https://doi.org/10.20527/jwm.v7i1.176

Hair, J. F., Black, W. C., Babin, B. J., \& Anderson, R. E. (2010). Multivariate Data Analysis. In Vectors. https://doi.org/10.1016/j.ijpharm.2011. 02.019

Hanafi, R., \& Hutomo, I. T. (2019). Pengaruh Store Atmosphere, Hedonic Shopping, Dan Promosi Terhadap Impulsive Buying. 8(September), 8796.

Hartaroe, B. P., Mardani, R. M., \& Abs, M. K. (2016). Pengaruh Visual Merchandising Dan Brand Personality Terhadap Impulse Buying Melalui Positive Emotion (Studi Pada Konsumen Matahari Department Store Malang Town Square). 82-94.

I Putu Widya Artana. (2019). Pengaruh store Atmosphere, Display poduct, dan pice Discount terhadap Impulse Buying. EJurnal Ekonomi Dan Bisnis.

Jain, V., Sharma, A., \& Narwal, P. (2012). Impact of Visual Merchandising on Consumer Behaviour towards Women's Apparel. International Journal of Research in Management Issue 2, 5(2), 106-117. http://www.rspublication.com/ijrm/ijr m_index.htm

Kollat, D. T., \& Willett, R. P. (1969). Is Impulse Purchasing Really a Useful Concept for Marketing Decisions? Journal of Marketing. https://doi.org/10.1177/002224296903 300113

Kwan, G. O. (2016). Pengaruh Sales Promotion Dan Store Atmosphere Terhadap Impulse Buying Dengan Positive Emotion Sebagai Variabel Intervening Pada Planet Sports Tunjangan Plaza Surabaya. Jurnal Manajemen Pemasaran.

Nofiawaty, beli yuliandi. (2014). pengaruh store atmosphere terhadap keputusan pembelian konsumen. Journal of Menegement and Bussines.

Pancaningrum, E. (2017). Visual Merchandise Dan Atmosfer Toko: Pengaruhnya Terhadap Keputusan Pembelian Impuls. Jurnal Ilmu Ekonomi Dan Pembangunan, 17(1), 23-40.

Rachmawati, V. (2009). Hubungan antara hedonic shopping value, positive emotion, dan perilaku impulse buying pada konsumen. Majalah Ekonomi.

Ratnasari, V. A., Kumadji, S., \& Kusumawati, A. (2015). Pengaruh store atmosphere terhadap hedonic shopping value dan impulse buying (survei pada konsumen Hypermart Malang Town Square ). Jurnal Administrasi Bisnis.

Sudarsono, J. G. (2017). Pengaruh Visual Merchandising Terhadap Impulse Buying Melalui Positive Emotion Pada 
Ayu Diah Ramaiska: Pengaruh Visual Merchandising Dan Store Atmosphere Terhadap Impulse Buying Dengan Positive Emotion Sebagai Variabel Mediasi Pada Konsumen Miniso Mall Kartini Bandar Lampung

Zara Surabaya. Jurnal Manajemen

Pemasaran, 11(1), 16-25.

https://doi.org/10.9744/pemasaran.11.

$1.16-25$ 